\title{
MUSCLE BIOPSY TECHNIQUE FOR ELECTROPHORESIS ANALYSIS OF FISH FROM THE GENUS Brycon
}

\author{
Alexandre Hilsdorf ${ }^{1,3}$, Danilo Caneppele ${ }^{2}$ and José Eduardo Krieger ${ }^{1}$
}

\begin{abstract}
Protein and mitochondrial DNA have been used as molecular markers to assess variability in stock identification studies of fishes. Protein and mtDNA used for electrophoretic analysis are extracted from tissues, which often leads to death of the individuals. In this study, we present a skeletal muscle biopsy procedure to extract mitochondrial DNA that does not require specimen sacrifice. Eighty pirapitinga-do-sul (Brycon opalinus) were biopsied by the present technique, with no mortalities recorded. Total DNA was extracted from muscle and digested by restriction enzymes Apal and Hpal. The mtDNA fragment patterns were hybridized with ${ }^{32} \mathrm{P}$-labeled pirapitinga-do-sul mtDNA probes. The described technique is simple and may be useful in protocols requiring tissue extraction for DNA and protein analyses without loss of the individual investigated.
\end{abstract}

\section{INTRODUCTION}

The genus Brycon belongs to the subfamily Bryconinae and has about 60 species (Howes, 1992), some of which are distributed throughout Brazilian watersheds (Géry and Mahnert, 1992). Anthropogenic influences have caused a reduction in natural populations of some Brycon species. For instance, in the Vale do Paraíba watershed, hydroelectric power plant dams, pollution and overfishing have brought the economically important Brycon insiginis (Piabanha) close to extinction (Salgado and Chain, 1997). Rehabilitation of endangered species depends on the ability to characterize natural and captivity populations. Evaluation of genetic differences within and among populations is the first step to a successful restocking program (Toledo-Filho et al., 1992).

Biochemical and molecular tools for identification of proteins (Revaldaves et al., 1997), mitochondrial DNA (Danzmann et al., 1991) and nuclear DNA (Wright, 1993) polymorphisms have been developed to study genetic variation in different fish species.

Population assessment or captivity stock discrimination using electrophoretic characterization requires a reliable source of biological material. The aim of this study was to establish a biopsy technique to obtain skeletal muscle samples from Brycon fish for mitochondrial DNA analysis without killing or seriously damaging the sampled individuals.

\footnotetext{
${ }^{1}$ Laboratório de Genética e Cardiologia Molecular do Instituto do Coração e Departamento de Clínica Médica, FMUSP, Av. Dr. Enéas L. Aguiar, 44, 05403-010 São Paulo, SP, Brasil. Send correspondence to A.H. E-mail: exphilsdorf@incor4.incor.usp.br

${ }^{2}$ Estação de Hidrobiologia e Piscicultura da CESP, Paraibuna, SP, Brasil. ${ }^{3}$ Departamento de Ciências Agrárias, Universidade de Taubaté, Taubaté, SP, Brasil.
}

\section{MATERIAL AND METHODS}

The present muscle biopsy technique was developed at the "Estação de Hidrobiologia e Piscicultura da Hidroelétrica de Paraibuna - CESP" using 80 Pirapitinga do sul (Brycon opalinus) individuals from the aquaculture station.

\section{Biopsy method}

Animals were anesthetized to equilibrium loss with benzocaine (ethyl-p-aminobenzoate) at a concentration of 1:5000 (Ross and Geddes, 1979). Scales were removed mid-way between the dorsal and adipose fins (Figure 1). Using a surgical blade, a longitudinal slice was removed from the dorsal region (Figure 2). Skeletal muscle tissue was then collected and stored in 95\% ethanol at room temperature until use. The biopsied area was treated with methylene blue (1\%) to prevent Saprolegnia growth. After equilibrium recovery, specimens were transferred to small tanks $\left(10 \mathrm{~m}^{3}\right)$, where $0.5 \%$ methylene blue was continuously added to the inlet water for an additional two days.

\section{Total DNA extraction}

Total DNA was extracted from the biopsied tissue according to the modified protocol of Taggart et al. (1992). Briefly, muscle was cut into small pieces and placed in $500 \mu \mathrm{l}$ STE buffer $(0.1 \mathrm{M} \mathrm{NaCl}, 0.05 \mathrm{M}$ Tris- $\mathrm{HCl}$ and $0.01 \mathrm{M} \mathrm{Na}_{2}$ EDTA, pH 8.0), $10 \mu \mathrm{l}$ SDS $10 \%$, and $30 \mu \mathrm{l}$ proteinase $\mathrm{K}(10 \mathrm{mg} / \mathrm{ml})$. The solution was left to digest for $2 \mathrm{~h}$ at $50^{\circ} \mathrm{C}$. The tubes were inverted several times to accelerate the digestion process. After the digestion process was concluded, $3 \mu \mathrm{l}$ of DNAse free-RNAse was added, and the suspension was incubated for $30 \mathrm{~min}$ at $37^{\circ} \mathrm{C}$. The resulting digestion mixture was extracted once with $500 \mu \mathrm{l}$ of buffer saturated phenol, $\mathrm{pH} 8$, once with pheno-chloroform-isoamyl alcohol (24:1), and once with chloroform-isoamyl alcohol. The DNA was then precipi- 


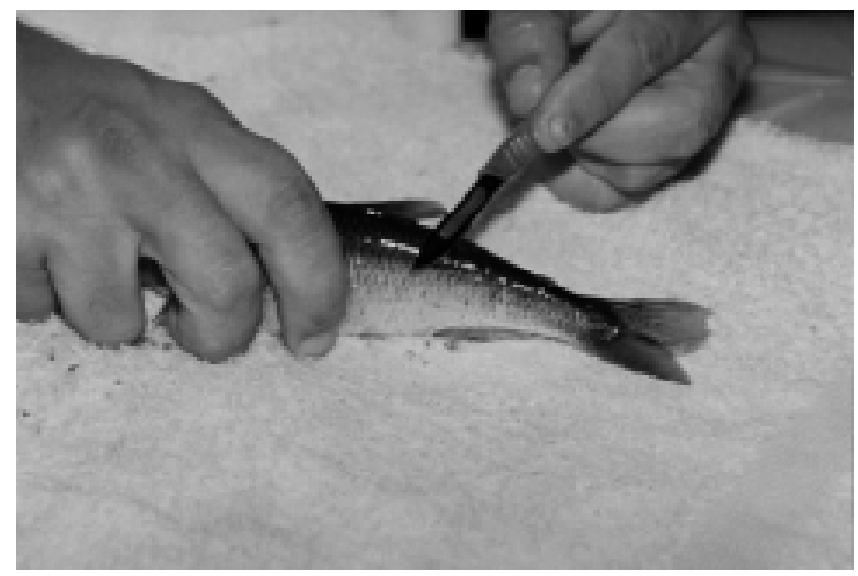

Figure 1 - Surgical blade position mid-way between dorsal and adipose fins for transversal cut procedure.

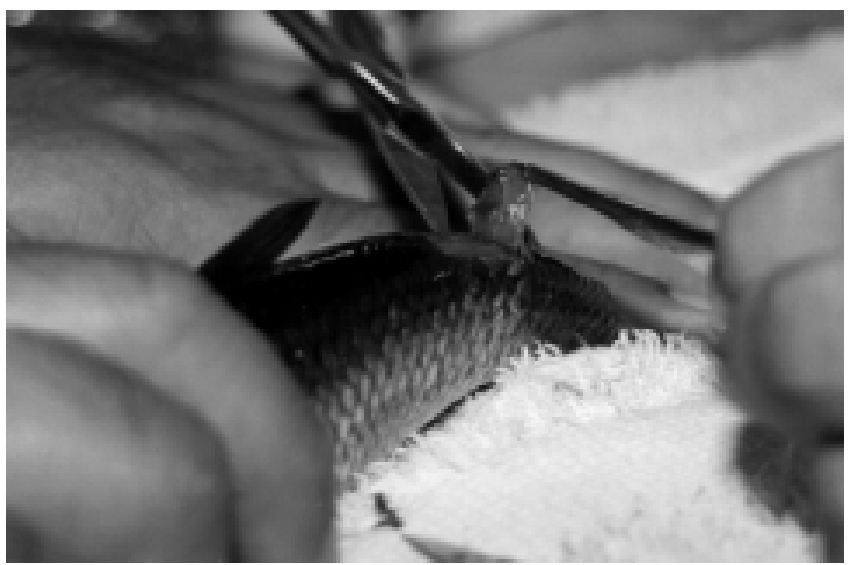

Figure 2 - Longitudinal slice for muscle biopsy.

tated in $1 \mathrm{ml}$ cold ethanol and sodium acetate $(3 \mathrm{M}, \mathrm{NaOAc}$, pH 5.3) (Maniatis et al., 1982). DNA pellets were dried and dissolved in $100 \mu \mathrm{l}$ TE buffer $(1 \mathrm{mM}$ Tris- $\mathrm{HCl}, 7.6$ and $0.1 \mathrm{mM}$ EDTA, pH 8.0).

\section{Mitochondrial DNA detection}

Two microliters of each total DNA extract was digested with restriction endonucleases ApaI (GGGCC/C) and $H p a \mathrm{I}$ (GTT/AAC). Digested DNA samples were run in $0.8 \%$ horizontal agarose gel $(7.7 \mathrm{~cm})$ for $1 \mathrm{~h}$. Gels were denatured $(0.5 \mathrm{M} \mathrm{NaOH}, 1.5 \mathrm{M} \mathrm{NaCl})$ and neutralized (1.0 M Tris- $\mathrm{HCl}, 1.5 \mathrm{M} \mathrm{NaCl}, \mathrm{pH}$ 7.2). Then, DNA fragments were immobilized on a nylon membrane (Biodyne ${ }^{\circledR}$ Membrane, Gibco BRL) by Southern transfer (Southern, 1975). Mitochondrial DNA was detected by hybridization with homologous probes of Brycon opalinus cloned at the Laboratório de Genética e Cardiologia Molecular, Instituto do Coração, INCOR. Briefly, mitochondrial DNA was isolated as described by Chapman and Powers (1984), then cut with the restriction enzyme $B a m H I$. The resulting frag- ments of 7.710, 4.930 and 2.125 base pairs were cloned into the Bluescript ${ }^{\circledR}$ plasmid (Stratagene) cut with the same enzyme. The homologous mtDNA probes were labeled with $\left[\alpha-{ }^{32} \mathrm{P}\right] \mathrm{dCTP}$ by random primer extension (ReadyTo-Go DNA labeling Beads (-dCTP), Pharmacia) for hybridization with total DNA muscle extractions.

\section{RESULTS AND DISCUSSION}

The development of sampling strategies to obtain genetic markers from protein and/or DNA is an essential step for genetic studies. A number of procedures have been described to obtain skeletal muscle tissue for protein electrophoresis analysis in population studies, stock management, and genetic improvement (Uthe, 1971; Crawford et al., 1977; McAndrew, 1981; Leitner and Isely, 1994). Muscle is a very important source of isozyme systems, and approximately $60 \%$ of the loci routinely used in genetic analysis is expressed in this tissue (Morizot et al., 1990). The amount of muscle tissue required for isozyme detection in the laboratorial procedure is 1-3 g (Falk et al., 1996). The technique presently described yielded an average of $2.8 \mathrm{~g}$ of muscle tissue from specimens with 12 to $25 \mathrm{~cm}$ in length, which is suitable for isozyme analysis.

In the present study, 80 specimens underwent biopsy. After 3 weeks, there were no mortalities, and the specimens were returned to their typical shoal environment. The wound caused by the biopsy healed completely within 2 weeks (Figure 3 ) without tissue necrosis or other serious local damage to the individuals. mtDNA fragments present in the total DNA extraction were efficiently hybridized with the ${ }^{32} \mathrm{P}$-labeled homologous probes and visualized after 12-h X-ray film exposure at room temperature (Figure 4). Mitochondrial DNA is an important genetic marker for phylogenetic and populational studies among different taxa (Avise and Lansman, 1983). mtDNA studies in fish have relied on soft-tissues such as liver, heart or kidney (Ferris and Berg, 1987) in which the donors are

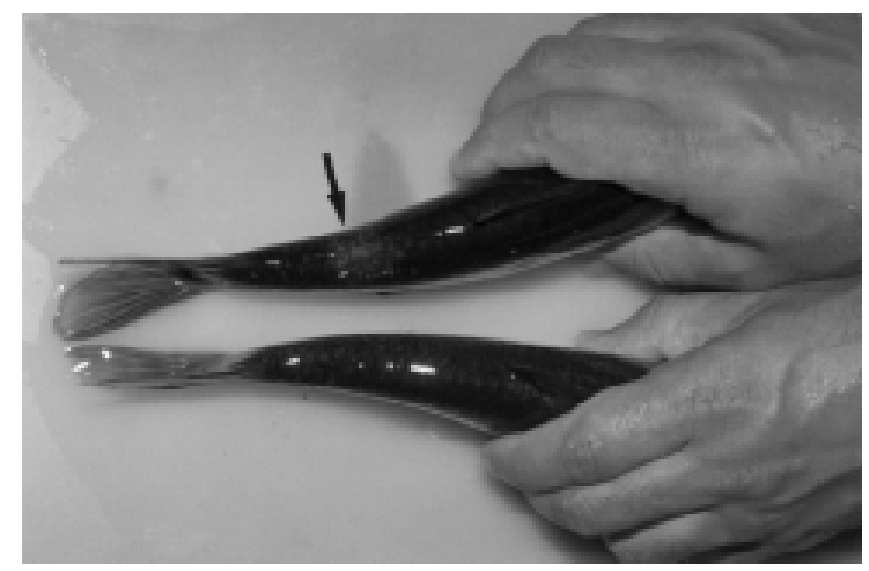

Figure 3 - Comparison between a biopsied animal (above) and non-biopsied one (below) after healing. 

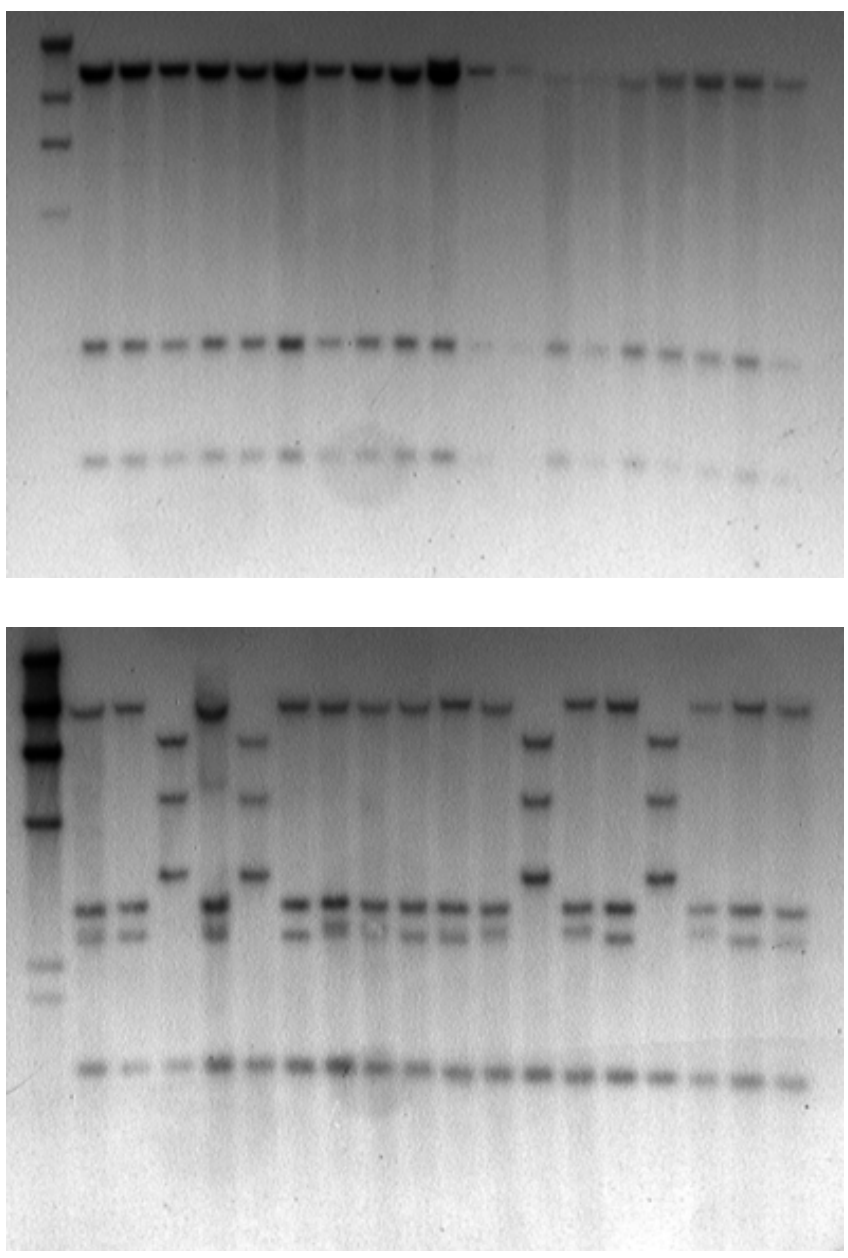

Figure 4 - Southern blots of $\mathrm{HpaI}$ and ApaI restriction fragments from Brycon opalinus mitochondrial DNA.

usually sacrificed for tissue removal. Nonlethal samples for total DNA extraction have been obtained from blood (Billington and Hebert, 1990) or adipose fins (Hilsdorf, A., unpublished results). However, in this case, mtDNA is present at a lower concentration than in muscle tissue; hence, total DNA yields from blood or adipose fins are expected to be less than the nonlethal DNA extractions from muscle tissue presently described.

Together, these findings demonstrate that muscle tissue from Brycon or Brycon-like species can be removed for mtDNA studies without sacrificing or seriously damaging the specimen. This technique can also be instrumental in genetical studies that require protein samples for electrophoresis analysis. Additionally, Southern blots initially probed for mtDNA can be reused for nuclear DNA analysis with suitable probes.

\section{ACKNOWLEDGMENTS}

We thank the CESP - Paraibuna staff, Lourenço Girardi, Benedito Barros and Adão J. Garcia for their technical assistance.
The research was supported by grants from FAPESP (No. 9546686), CNPq (No. 520696/95-6) and FINEP (No. 66.93.0023.00). Alexandre Hilsdorf is the recipient of a Doctoral fellowship from CNPq to develop graduate studies in the Department of Physiology and Biophysics, IB, UNICAMP. Publication supported by FAPESP.

\section{RESUMO}

Variabilidade apresentada por proteínas e pelo DNA mitocondrial tem sido utilizada em estudos populacionais de peixes. A obtenção de tecido para análise eletroforética de proteína e DNA mitocondrial muitas vezes requer a morte dos indivíduos. No presente trabalho, nós apresentamos uma técnica modificada para biopsia de tecido muscular sem a morte dos animais. Oitenta Pirapitingas-do-sul (Brycon opalinus) foram biopsiadas pela presente técnica, não tendo sido observado mortalidade. O DNA total foi extraído do tecido muscular e digerido com as enzymas de restrição ApaI e HpaI. Os fragmentos de DNA mitocondrial foram hibridizados com sondas de DNA mitocondrial de pirapitinga-do-sul marcadas com $\mathrm{P}^{32}$. A técnica descrita pode ser útil em estudos genéticos em peixes.

\section{REFERENCES}

Avise, J.C. and Lansman, R.A. (1983). Polymorphism of mitochondrial DNA in higher animals. In: Evolution of Genes and Proteins (Nei, M. and Koehn, R.K., eds). Sinaeur Associates, Suderland, MA.

Billington, N. and Hebert, P.D.N. (1990). Technique for determining mitochondrial DNA markers in blood samples from Walleyes. Am. Fish. Soc. Symp. 7: 492-498.

Chapman, R.W. and Powers, D.A. (1984). A method for the rapid isolation of mitochondrial DNA from fishes. Technical Report \#UM-SGTS-84-05, Maryland Sea Grant Program, College Park, MD.

Crawford, B.A., Leider, S.A. and Tipping, J.M. (1977). Technique for rapidly taking samples of skeletal muscle from live adult steelhead trout. Progr. Fish-Cult. 39: 125.

Danzmann, R.G., Ihssen, P.E. and Hebert, P.N.D. (1991). Genetic discrimination of wild and hatchery populations of brook charr, Salvelinus fontinais (Mitchill), in Ontario using mitochondrial DNA analysis. J. Fish Biol. 39 (Suppl. A): 69-77.

Falk, T.M., Abban, E.K., Oberst, S., Villwock, W., Pullin, R.S.V. and Renwrantz, L. (1996). A Biochemical Laboratory Manual for Species Characterization of some Tilapiine Fishes. ICLARM - International Center for Living Aquatic Resources Management, Educ. Ser., Manila, 17: 93.

Ferris, S.D. and Berg, W.J. (1987). The utility of mitochondrial DNA in fish genetics and management. In: Population Genetics and Fisheries Management (Ryman, N. and Utter, F., eds.). University of Washington Press, Seattle, WA, pp. 277-301.

Géry, J. and Mahnert, V. (1992). Notes sur quelques Brycon des bassins de l'Amazone, du Parana-Paraguay et du sud-est brésilien (Pisces, Characiformes, Characidae). Rev. Suisse Zool. 99: 793-819.

Howes, G. (1982). Review of the genus Brycon (Teleostei: Characoidei). Bull. Br. Mus. Nat. Hist. (Zool) 43: 1-47.

Leitner, J.K. and Isely, J.J. (1994). A liver and muscle biopsy technique for electrophoretic evaluation of Largemouth Bass. Progr. Fish-Cult. 56: 288-290.

McAndrew, B.J. (1981). Muscle biopsy technique for fish stock management. Vet. Rec. 108: 516.

Maniatis, T., Fritsch, E.F. and Sambrook, J. (1982). Molecular Cloning: A Laboratory Manual. Cold Spring Harbor Laboratory, Cold Spring, NY.

Morizot, D.C., Schmidt, M.E., Carmichael, G.J., Stock, D.W. and Williamson, H.T., (1990). Minimally invasive tissue sampling. In: Electrophoretic and Isoelectric Focusing Techniques in Fisheries 
Management (Whitmore, D.H., ed.). CRC Press Inc., Boca Raton, FL, pp. 143-156.

Revaldaves, E., Renesto, E. and Machado, M.F.P.S. (1997). Genetic variability of Prochilodus lineatus (Characiformes, Prochilodontidae) in the upper Paraná River. Braz. J. Genet. 20: 381-388.

Ross, I.G. and Geddes, J.A. (1979). Sedation of warm-water fish species in Aquaculture research. Aquaculture 16: 183-186.

Salgado, F.G.A. and Chain, M.G. (1997). O Salvamento de uma Espécie em Extinção: A Conservação da Piabanha (Brycon insignis) na Bacia do Rio Paraíba do Sul. CESP-Companhia Energética de São Paulo, São Paulo.

Southern, E.M. (1975). Detection of specific sequences among DNA fragments separated by electrophoresis. J. Mol. Biol. 98: 503-517.
Taggart, J.B., Hynes, R.A., Prodohl, P.A. and Fergusson, A. (1992). A simplified protocol for routine total DNA isolation from salmonid fishes. J. Fish Biol. 40: 963-965.

Toledo-Filho, S.A., Almeida-Toledo, L.F., Foresti F., Galhardo, E. and Donola, E. (1992). Conservação genética de peixes em projetos de repovoamento de reservatórios. Cadernos de Ictiologia 1: 1-39.

Uthe, J.J. (1971). A simple field technique for obtaining small samples of muscle from living fish. J. Fish. Res. Board Can. 28: 1203-1204.

Wright, J.M. (1993). DNA fingerprinting in fishes. In: Biochemistry and Molecular Biology of Fishes (Hochachka, P. and Mommsen, T., eds.). Vol. 2. Elsevier, Amsterdam, pp. 57-91.

(Received November 25, 1998) 